\title{
Atrial natriuretic peptide and water and electrolyte transport in the human jejunum
}

\author{
J Brunner, R Lübcke, G O Barbezat, T G Yandle, E A Espiner
}

\begin{abstract}
The effects of atrial natriuretic peptide were investigated on water and electrolyte transport in the human jejunum. Six healthy male volunteers (aged 21-33 years) were studied using a triple lumen perfusion technique. A plasma like electrolyte solution containing polyethylene glycol $(5 \mathrm{~g} / \mathrm{l})$ as a non-absorbable marker was perfused into the jejunum at $10 \mathrm{ml} / \mathrm{min}$, and net water and electrolyte transport and transepithelial potential difference were measured. Subjects were studied single blind on two occasions with either intravenous atrial natriuretic peptide $(6 \mathrm{pmol} / \mathrm{min} / \mathrm{kg}$ for 90 minutes) or placebo (saline), both after controlled sodium intake over three days. Plasma atrial natriuretic peptide concentrations rose from (mean (SD)) 10.3 (3.6) pmol/l to a peak of 96.0 (61.8) pmol/1. Jejunal net water and electrolyte fluxes and potential difference were identical in both the atrial natriuretic peptide and the control studies. Compared with placebo atrial natriuretic peptide induced a significantly greater diuresis (peak $10 \cdot 2(6 \cdot 0) v$ $1.8(1.0) \mathrm{ml} / \mathrm{min}, \mathrm{p}<0.05$ ) and natriuresis (peak 1069 (351) v 376 (208) $\mu \mathrm{mol} / \mathrm{min}, \mathrm{p}<0.01$ ) and haemoconcentration (haematocrit 0.405 $(0.040) v 0.368(0.018), \mathrm{p}<0.01)$. There was no difference in blood pressure, pulse rate, plasma electrolytes, and plasma osmolality between the two studies. There was no evidence to suggest an effect of atrial natriuretic peptide on jejunal water and electrolyte transport in healthy human subjects.
\end{abstract}

Atrial natriuretic peptide is a hormone which has been found in a variety of species. ${ }^{1}$ The 126 amino acid propeptide is synthesised and stored in atrial myocytes. The most important biologically active natriuretic peptide released into the circulation is $\alpha$ atrial natriuretic peptide, the 99-126 fraction at the $\mathrm{C}$-terminal end. In humans acute volume load with saline, high sodium intake, or conditions with increased extracellular volume such as chronic heart and renal failure, result in increased plasma atrial natriuretic peptide concentrations. ${ }^{2}$ Intravenously infused synthetic human $\alpha$ atrial natriuretic peptide in normal subjects induces diuresis, natriuresis, and haemoconcentration, ${ }^{34}$ can lower blood pressure, ${ }^{5}$ and inhibits renin and aldosterone secretion. ${ }^{6}$ Given these effects, it seems likely that atrial natriuretic peptide has a physiological role in the regulation of sodium balance and extracellular volume. Atrial natriuretic peptide receptors are found in various organs including the jejunum of the rat. ${ }^{78}$ The effect of this hormone on small intestinal transport has not been extensively studied and the available data in animals $^{8-11}$ and humans ${ }^{12}$ are controversial. Our aim was therefore to investigate whether human atrial natriuretic peptide, infused intravenously in doses simulating pathophysiological blood concentrations, has an effect on water and electrolyte transport in the human jejunum using the triple lumen perfusion technique.

\section{Methods}

Six normal male volunteers aged 21-33 years (mean 24 years) were studied. Informed written consent was obtained from all subjects and the study protocol was approved by the Otago Hospital Board Ethics Committee.

\section{STUDY PROTOCOL}

Each subject was studied on two separate occasions at least one week apart, once with intravenous atrial natriuretic peptide and once with placebo. The subjects were on a specially composed diet with fixed sodium and potassium intakes of 150 and $70 \mathrm{mmol} /$ day respectively for three days before each study. They were not admitted to hospital for this period. On the third day of the diet a 24 hour urine collection was made to measure electrolyte excretion and creatinine clearance. One subject did not complete the 24 hour collection on one occasion and all his urine baseline data for both tests were excluded from the final analysis. On the fourth day the volunteers were intubated with the intestinal perfusion tube at $\mathbf{0 7 0 0}$ hours after an overnight fast. They then remained supine for the rest of the study, apart from brief periods of standing to pass urine. One intravenous cannula was inserted in each arm, one for blood sampling and the other for intravenous atrial natriuretic peptide/placebo infusion. A subcutaneous cannula was placed in one arm for potential difference measurements. The study consisted of a first control period ( 60 minutes, time -60 to 0 ), the active period ( 90 minutes, time 0 to 90 ), and a second control period (60 minutes, time 90 to 150). During the active period $\alpha$ human atrial natriuretic peptide or placebo (saline) was infused intravenously at $0.5 \mathrm{ml} / \mathrm{min} ; \alpha$ human atrial natriuretic peptide (Bachem, Torrance, CA) was dissolved, dispensed in $250 \mu \mathrm{g}$ aliquots, and lyophilised as described previously. ${ }^{3}$ Atrial natriuretic peptide vials (or the same volume of saline for control infusions) were reconstituted on the study day and made up to the appropriate volume in Haemaccel (Behringwerke AG, Marburg a.d. Lahn, Germany). ${ }^{3}$ The effectively infused dose of hormone based on the assay of infusates was $6 \cdot 2(1 \cdot 8) \mathrm{pmol} / \mathrm{min} / \mathrm{kg}$. Atrial natriuretic peptide and control infusions were randomised and performed single blind. Plasma electrolytes, plasma 
osmolality, and haematocrit were checked at time $-60,0,90$, and 150 minutes. Venous blood samples for measuring plasma atrial natriuretic peptide concentrations (drawn at 15 minute intervals during the infusion period and at 30 minute intervals before and after infusions) were collected on ice in tubes containing ethylenediaminetetra-acetate. The samples were immediately spun at $4^{\circ} \mathrm{C}$ and stored at $-80^{\circ} \mathrm{C}$ until assayed. Urine samples were obtained at 30 minute intervals. After recording the volume, samples were taken to meásure osmolality and electrolytes. One volunteer was unable to pass urine at the required times and was therefore excluded from that part of the analysis. Blood pressure and pulse rate were monitored at 15 minute intervals using an oscillometric, programmable blood pressure monitor with a digital display (Model 90202 Ambulatory Blood Pressure Monitor, SpaceLabs, Washington).

\section{INTESTINAL PERFUSION}

The subjects were intubated with a standard triple lumen perfusion tube ${ }^{13}$ including a $15 \mathrm{~cm}$ mixing and $30 \mathrm{~cm}$ test segment. The infusion site was placed beyond the ligament of Treitz and its position was checked radiologically using an image intensifier. A plasma like electrolyte solution containing $(\mathrm{mmol} / \mathrm{l}) \mathrm{Na}^{+} 140, \mathrm{~K}^{+} 5, \mathrm{Cl}^{-} 110$, $\mathrm{HCO}_{3}^{-} 35$ was perfused at $10 \mathrm{ml} / \mathrm{min}$ using a peristaltic pump (Harvard Apparatus, Millis, Mass). Polyethylene glycol (PEG 4000, 5 g/l) was added as non-absorbable volume marker. Fifteen minutes after starting the perfusion, aspirations from the proximal and distal aspiration points were started at $1 \mathrm{ml} / \mathrm{min}$ using syringe pumps (Sage, Model 351, Cambridge, Mass). The first 15 minute collection was discarded. After a further 30 minutes consecutive 15 minute collections were made for measurement of net water and electrolyte fluxes. ${ }^{14}$ A 10 minute stagger period was allowed between proximal and distal aspirations. A sample of each aspirate was kept on ice and stored at $-80^{\circ} \mathrm{C}$ for measurement of cyclic guanosine monophosphate. The $\mathrm{pH}$ of the aspirates was measured immediately after collecting.

\section{POTENTIAL DIFFERENCE}

Intestinal transepithelial potential difference was measured as described previously. ${ }^{\text {is }}$ It was measured continuously between the infusion tube, which served as flowing intraluminal electrode, and a subcutaneous reference electrode consisting of a saline filled plastic cannula inserted into the subcutaneous tissue of the right forearm. Intraluminal electrode and reference electrode were connected to an electrometer (Keithley Instruments, Cleveland, Ohio) via $3 \mathrm{M} \mathrm{KCl}$ agar

TABLE I Mean (SD) 24 hour urinary electrolyte excretion and creatinine clearance before atrial natriuretic peptide $(A N P) / p l a c e b o$ studies $(n=5)$

\begin{tabular}{lllll}
\hline $\begin{array}{l}\mathrm{Na}^{+} \\
(\mathrm{mmol} / \mathrm{l})\end{array}$ & $\begin{array}{l}\mathrm{K}^{+} \\
(\mathrm{mmol} / 24 \mathrm{~h})\end{array}$ & $\begin{array}{l}\mathrm{Cl} \\
(\mathrm{mmol} / \mathrm{l})\end{array}$ & $\begin{array}{l}\mathrm{CrCl} \\
(\mathrm{ml} / \mathrm{min})\end{array}$ \\
\hline ANP & $158.0(48 \cdot 1)$ & $\begin{array}{l}80 \cdot 1(10 \cdot 9) \\
\mathrm{p}<0.05\end{array}$ & $\begin{array}{l}149 \cdot 0(26 \cdot 8) \\
\mathbf{p}<0.05\end{array}$ & $117 \cdot 3(22 \cdot 9)$ \\
Saline & $135.0(37 \cdot 2)$ & $62 \cdot 6(14 \cdot 2)$ & $121 \cdot 4(22 \cdot 4)$ & $107.6(21 \cdot 0)$ \\
\hline
\end{tabular}

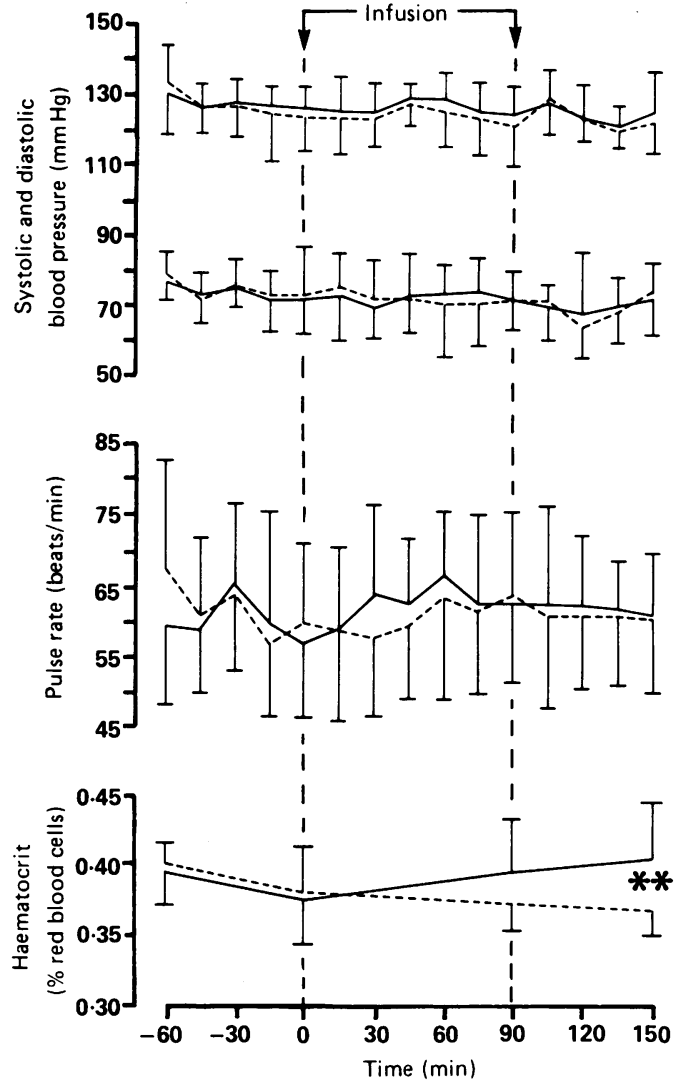

Figure 1: Mean (SD) arterial blood pressure, pulse rate, and haematocrit before, during, and after infusion of $\alpha$ human atrial natriuretic peptide $(-)$ or placebo (saline, -- ) in six normal men. ${ }^{\star \star} p<0.01$

bridges and $\mathrm{Ag}-\mathrm{AgCl}$ electrodes. The potential difference was displayed on a chart recorder (Rikadenki, Tokyo, Japan). For technical reasons two subjects had recordings on only one occasion and were excluded from analysis.

\section{ANALYTICAL METHODS}

Sodium and potassium (Flamephotometer), chloride (Chloridometer), bicarbonate (acid back-titration), creatinine and haematocrit (Autoanalyser) were measured by standard laboratory techniques. Osmolality was measured by depression of freezing point (Fiske Osmometer, Uxbridge, Mass). Polyethylene glycol was measured using an improved turbidimetric method of Malawer and Powell. ${ }^{16}$ Plasma immunoreactive atrial natriuretic peptide was measured in venous plasma extracts as previously described ${ }^{1}$ except that a locally raised antiserum (R27) ${ }^{17}$ was substituted for Peninsula antiserum and plasma samples were extracted using vycor glass powder $(0.5 \mathrm{mg} / 1 \mathrm{ml}$ plasma). Extraction efficiency was $85 \%$. Cyclic guanosine monophosphate concentrations in the jejunal aspirates and urine were measured by radioimmunoassay using a commercially available kit (Amersham, TRK.500). Urine was diluted 1:10 with water before assaying and jejunal aspirates underwent an ethanol extraction procedure.

\section{STATISTICS}

Results are expressed as mean (SD). Results from test and control studies were compared by 
Figure 2: Mean (SD) plasma atrial natriuretic peptide concentrations before, during, and after infusion of $\alpha$ human atrial natriuretic peptide $(\mathrm{O})$ or placebo (saline, $\bigcirc$ ) in six normal men.

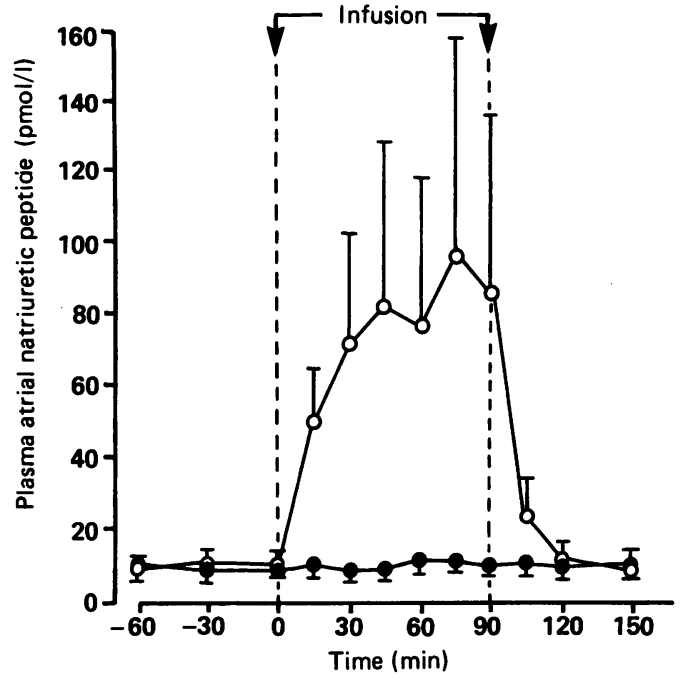

Student's $t$ test for paired data. p values of $<0.05$ were regarded as significant.

\section{Results}

None of the subjects experienced any adverse effects during atrial natriuretic peptide infusion. The urinary electrolyte excretion was higher before the test days than before the control days (Table I). The difference was significant for potassium and chloride, but not for sodium. Renal function as assessed by creatinine clearance was identical before test and control days (Table I).

\section{BLOOD PRESSURE, PULSE RATE, AND PLASMA VALUES (Figs 1 and 2)}

There was no difference between atrial natriuretic peptide and control studies in systolic and diastolic blood pressure and pulse rate (Fig 1). Plasma osmolality and plasma electrolytes remained normal throughout the study and there was no difference between active and control days. While the haematocrit dropped slightly during the control studies, it steadily increased after starting the atrial natriuretic peptide infusion and was significantly higher at the end of the study (Fig 1). The plasma atrial natriuretic peptide concentrations remained within normal limits during the control studies and increased from $10.3(3.6)$ to a peak of $96.0(61.8) \mathrm{pmol} / 175$ minutes after starting the atrial natriuretic peptide infusion (Fig 2); they returned to baseline values within 30 minutes of stopping the infusion.

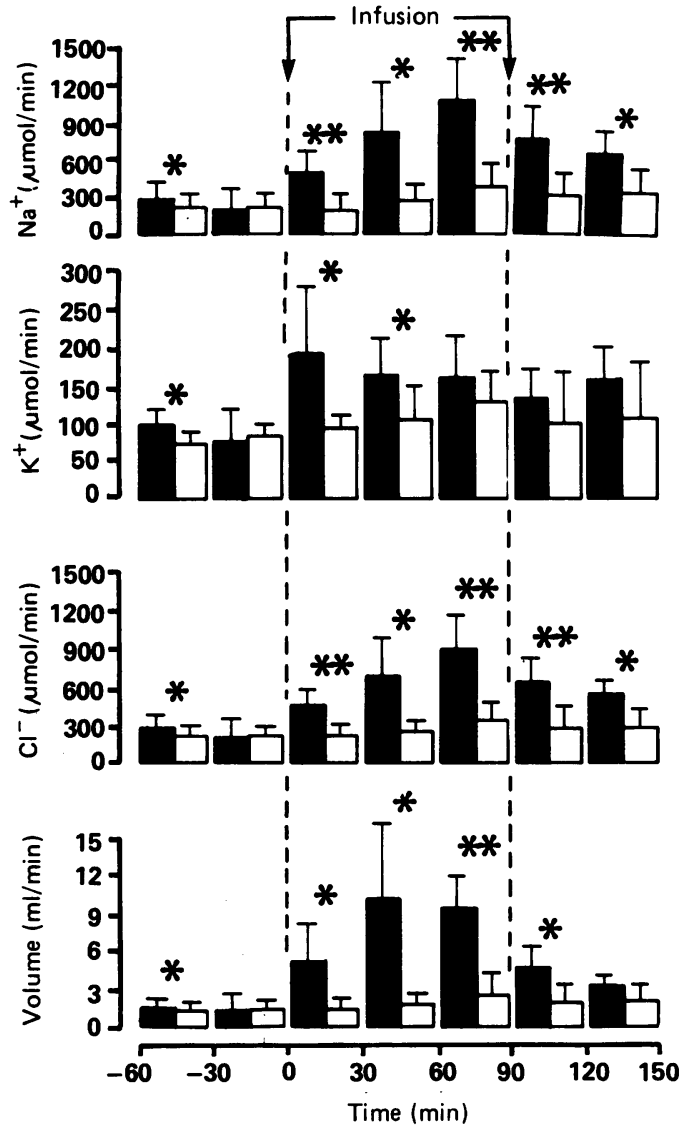

Figure 3: Mean (SD) urinary electrolyte and volume excretion before, during, and after infusion of a human atrial natriuretic peptide ( $)$ or placebo (saline, $\square$ ) in five normal natriuretic peptide $(\mathbf{\square})$ or place
men. ${ }^{\star} p<0.05,{ }^{\star \star} p<0.01$

URINARY RESPONSE (Fig 3)

During the first 30 minutes of the experiments urinary electolyte excretion and diuresis were slightly but significantly higher on the $\alpha$ atrial natriuretic peptide days compared with the placebo days. There was no longer any difference during the second half hour of the first control period. Hormone infusion resulted in a fourfold increase of sodium and chloride excretion, which remained significantly higher for 60 minutes after stopping the infusion. Potassium excretion increased significantly in the first 60 minutes of the infusion. Urine volume increased sixfold and the diuretic effect was maintained for 30 minutes after completion of the infusion.

\section{JEJUNAL WATER AND ELECTROLYTE TRANSPORT} (Table II)

Net water and electrolyte fluxes, transepithelial and after intravenous atrial natriuretic peptide (ANP) (ifference, and pH of aspirates in the human

\begin{tabular}{|c|c|c|c|c|c|c|}
\hline & \multicolumn{2}{|c|}{ Control period (30 min) } & \multicolumn{2}{|c|}{ Active period (90 min) } & \multicolumn{2}{|c|}{ Control period $(60 \mathrm{~min})$} \\
\hline & $A N P$ & Saline & $A N P$ & Saline & $A N P$ & Saline \\
\hline $\begin{array}{l}\Delta \mathrm{H}_{2} \mathrm{O}(\mu \mathrm{l} / \mathrm{cm} / \mathrm{min}) \\
\Delta \mathrm{Na}^{+}(\mu \mathrm{mol} / \mathrm{cm} / \mathrm{min}) \\
\Delta \mathrm{K}^{+}(\mu \mathrm{mol} / \mathrm{cm} / \mathrm{min}) \\
\Delta \mathrm{Cl}^{-}(\mu \mathrm{mol} / \mathrm{cm} / \mathrm{min}) \\
\Delta \mathrm{HCO}_{3}^{-}(\mu \mathrm{mol} / \mathrm{cm} / \mathrm{min}) \\
\text { Potential difference }(\mathrm{mV}) \\
(\mathrm{n}=4) \\
\mathrm{pH}\end{array}$ & $\begin{array}{c}46.4(17.6) \\
6.52(2.45) \\
0.31(0.14) \\
3.44(2.07) \\
2.61(1.03) \\
-0.2(1.4)\end{array}$ & $\begin{array}{c}43.9(25.4) \\
5.72(3.74) \\
0.29(0.24) \\
2.98(2.09) \\
3.01(0.96) \\
-0.9(0.6)\end{array}$ & $\begin{array}{l}46.9(13.0) \\
6.62(1.65) \\
0.31(0.08) \\
3.26(1.56) \\
3.00(0.74) \\
0(1.5) \\
\end{array}$ & $\begin{array}{c}47.4(37.3) \\
6.95(5.36) \\
0.31(0.23) \\
3.35(4.85) \\
2.96(0.82) \\
-0.2(1 \cdot 1)\end{array}$ & $\begin{array}{c}53.9(42.3) \\
7.47(6.25) \\
0.33(0.29) \\
3.98(6.25) \\
3.56(0.70) \\
-0.7(0.9)\end{array}$ & $\begin{array}{c}49.6(20.1) \\
7.18(3.02) \\
0.31(0.12) \\
3.67(3.20) \\
2.97(0.51) \\
-0.6(0.9)\end{array}$ \\
\hline $\begin{array}{l}\text { Proximal aspirates } \\
\text { Distal aspirates }\end{array}$ & $\begin{array}{l}7.03(0.22) \\
6.78(0.10)\end{array}$ & $\begin{array}{l}7.02(0.35) \\
6.79(0.32)\end{array}$ & $\begin{array}{l}7.05(0.18) \\
6.71(0 \cdot 11)\end{array}$ & $\begin{array}{l}6.99(0.25) \\
6.68(0.27)\end{array}$ & $\begin{array}{l}7.08(0.29) \\
6.71(0.24)\end{array}$ & $\begin{array}{l}7 \cdot 10(0 \cdot 23) \\
6 \cdot 70(0 \cdot 14)\end{array}$ \\
\hline
\end{tabular}


TABLE III Mean (SD) jejunal c-GMP output (pmol/min) at the proximal aspiration point before, during, and after intravenous atrial natriuretic peptide (ANP) or placebo infusion $(n=6)$

\begin{tabular}{|c|c|c|c|c|}
\hline \multirow[b]{2}{*}{ Aspirates } & \multicolumn{4}{|l|}{ Minutes } \\
\hline & $-15-0$ & $30-45$ & $75-90$ & $135-150$ \\
\hline $\begin{array}{l}\text { ANP } \\
\text { Saline }\end{array}$ & $\begin{array}{l}3.7(2.2) \\
3.4(1.6)\end{array}$ & $\begin{array}{l}3.5(1.0) \\
3.5(1.2)\end{array}$ & $\begin{array}{l}4 \cdot 8(3 \cdot 2) \\
4 \cdot 2(1 \cdot 3)\end{array}$ & $\begin{array}{l}2.8(1.6) \\
4.3(2.4)\end{array}$ \\
\hline
\end{tabular}

potential difference, and $\mathrm{pH}$ of jejunal aspirates remained constant during the active period and both control periods, and no difference was observed between the results of the placebo and atrial natriuretic peptide studies.

CYCLIC GUANOSINE MONOPHOSPHATE (C-GMP) CONCENTRATIONS IN JEJUNAL ASPIRATES AND URINE (Table III)

c-GMP concentrations were measured in the proximal jejunal aspirates of the collections at $-15-0,30-45,75-90$, and $135-150$ minutes. There was no difference in the output of c-GMP at the proximal aspiration site between atrial natriuretic peptide and control studies (Table III). In two subjects urinary c-GMP excretion was measured in the last 30 minute collection of the active period (60-90 minutes). During atrial natriuretic peptide infusion c-GMP excretion was higher than during placebo infusion $(16.7 v$ $2.6 \mathrm{pmol} / \mathrm{min}$ and $28.1 \mathrm{pmol} / \mathrm{min} v 2.6 \mathrm{pmol} /$ $\min )$.

\section{Discussion}

This study failed to show an effect of human $\alpha$ atrial natriuretic peptide on jejunal water and electrolyte transport when given in a dose aimed and shown to reproduce atrial natriuretic peptide plasma concentrations which are found in humans under pathophysiological conditions such as chronic renal failure ${ }^{18}$ and chronic heart failure. ${ }^{19} 20$

In the jejunum atrial natriuretic peptide receptors are localised in the mucosa beneath the columnar epithelium in the area of the villi but not the crypts, ${ }^{721}$ suggesting a possible influence on the absorptive properties of this intestinal segment. Published data on the effects of atrial natriuretic peptide on small intestinal transport are controversial. In rats some workers have shown increased ${ }^{8}$ and some decreased ${ }^{92}$ effects on net absorption. In our own studies in rats ${ }^{23}$ we showed that pharmacological doses (raising plasma concentrations by a factor of 130) had no effect on jejunal transport or colonic electrical parameters; however, even larger doses (raising plasma concentrations by a factor of over 1400) decreased net absorption and even induced secretion in the jejunum, but had no effect on the colon. This effect may well have been a nonspecific or even 'toxic' response.

The only study of human transport, by Petritsch et $a l,{ }^{12}$ investigated both the jejunum and the ileum. The data gained from the jejunum are in agreement with our findings. In that study, however, the subjects were investigated on only one occasion and did not have a control perfusion with placebo infusion on a separate day. Since perfusions constitute an intestinal volume load, this itself could stimulate endogenous atrial natriuretic peptide secretion. In our study plasma concentrations remained unchanged during control perfusions, indicating that the net intestinal saline load of $10 \mathrm{ml} / \mathrm{min}$ was not enough to release endogenous atrial natriuretic peptide. Petritsch et $a l^{12}$ also reported similar plasma concentrations at the beginning and end of their perfusion period, which mitigates against appreciable volume load. It seems possible that more pronounced volume loading, especially together with the application of exogenous atrial natriuretic peptide, may decrease net intestinal absorption.

Blood volume expansion, a known stimulus to atrial natriuretic peptide release, decreased sodium and water absorption in the $\operatorname{dog}^{24}$ and the rat. ${ }^{92}$ A c-GMP mediated atrial natriuretic peptide effect, previously reported in rats, ${ }^{25}$ might be involved. In humans intravenous infusion increased plasma concentrations of c-GMP and increased urinary c-GMP excretion. ${ }^{26}$ Tissue c-GMP released into the extracellular space $^{27}$ should be detectable in jejunal aspirates; however, we were unable to show differences in jejunal c-GMP output between atrial natriuretic peptide and control studies (Table III). In contrast, urinary c-GMP excretion increased sixfold to 11-fold during the diuresis accompanying atrial natriuretic peptide infusion (tested in two subjects). This provides convincing evidence of c-GMP mediated bioactivity of the infused atrial natriuretic peptide in the kidneys ${ }^{26}$ but not in the gut.

This study was supported by a grant from the Swiss National Fund and with the assistance of the National Heart Foundation of New Zealand.

1 DeBold AJ, Borenstein HB, Veress AT, Sonnenberg H. A rapid and potent natriuretic response to intravenous injection of atrial myocardial extracts in rats. Life Sci $1981 ; 28$ 89-94.

2 Espiner EA, Nicholls MG. Human atrial natriuretic peptide. Clin Endocrinol 1987; 26: 637-50.

3 Cuneo RC, Espiner EA, Nicholls MG, Yandle TG. Joyce SL Gilchrist NL. Renal, hemodynamic, and hormona responses to atrial natriuretic peptide infusions in normal man, and effect of sodium intake. $\mathcal{F}$ Clin Endocrinol Metab 1986; 63: 946-53.

4 Richards AM, Tonolo G, Montorsi P, et al. Low dose infusion of 26- and 28-amino acid human atrial natriuretic peptides in normal man. F Clin Endocrinol Metab 1988; 66: 465-72.

5 Weidmann $P$, Hasler L, Gnädinger MP, et al. Blood levels and renal effects of atrial natriuretic peptide in normal man $\mathcal{F}$ Clin Invest 1986; 77: 734-42.

6 Cuneo RC, Espiner EA, Nicholls MG, Yandle TG, Livesey JH. Effect of physiological levels of atrial natriuretic peptide on hormone secretion: inhibition of angiotensin-induced aldosterone secretion and renin release in normal man. $f \mathrm{Clin}$ Endocrinol Metab 1987; 65: 1697-701.

7 Bianchi C, Gutkowska J, Thibaut G, Garcia R, Genest J, Cantin M. Radioautographic localization of '"'I-atrial natriuretic factor (ANF) in rat tissues. Histochemistry 1985 82: 441-52.

8 Kanai Y, Ohnuma N, Matsuo H. Rat atrial natriuretic polypeptide increases net water, sodium and chloride absorption across rat small intestine in vivo. F p $\mathcal{F}$ P harmaco 1987; 45: 7-13.

9 Martinez-Seeber A, Vidal NA, Carchio SM, Karara AL. Inhibition of water-sodium intestinal absorption by an atria extract. Can F Physiol Pharmacol 1986; 64: 244-7.

10 Gonvers JJ, Winistörfer B, Mirkovitch V, de Vane $\mathrm{Ph}$ Brunner HR. Atrial natriuretic peptide decreases net wate and sodium absorption in dog jejunum. Gastroenterology 1987; 92: 1408 .

11 Kaufman S, Monckton E. Influence of right atrial stretch and atrial natriuretic factor on rat intestinal fluid content. f Physiol 1988; 402: 1-8.

12 Petritsch W, Holzer-Petsche U, Hinterleitner T, Krejs GJ Intravenous atrial natriuretic peptide does not affect water
and electrolyte transport in the human small intestine. Eur $\mathcal{F}$ and electrolyte transport in the

13 Schmitt MG, Wood CM, Soergel KH. A method for rapid placing of small intestinal perfusion tubes. Gut 1974; 15: 227-8. 
14 Cooper H, Levitan R, Fordtran JS, Ingelfinger FJ. A method for studying absorption of water and solute from the human for studying absorption of water and solute from

15 Davis GR, Santa Ana CA, Morawski SG, Fordtran JS Permeability characteristics of human jejunum, ileum, proximal colon and distal colon: Results of potential difference measurements and unidirectional fluxes. Gastroenterology 1982: 83: 844-50.

16 Malawer SJ, Powell DW. An improved turbidimetric analysis of polyethylene glycol utilizing an emulsifier. Gastroenterology 1967; 53: $250-6$

17 Yandle TG, Crozier IG, Nicholls MG, Espiner EA, Carne A, Brennan S. Amino acid sequence of atrial natriuretic peptides in human coronary sinus plasma. Biochem Biophys Res Commun 1987; 146: 832-9.

18 Anderson JV, Raine AEG, Proudler A, Bloom SR. Effect of haemodialysis on plasma concentrations of atrial natriuretic peptide in adult patients with chronic renal failure. peptide in adult patients with

19 Anderson JV, Woodruff PWR, Bloom SR. The effect of treatment of congestive heart failure on plasma atrial natriuretic peptide concentration: a longitudinal study. $B r$ Heart F 1988; 59: 207-11.

20 Crozier IG, Nicholls MG, Ikram H, Espiner EA, Gomez HJ, Warner NJ. Haemodynamic effects of atrial peptide infusion in heart failure. Lancet 1986; ii: $1242-5$.

21 Vuolteenaho $O$, Arjamaa $O$, Vakkuri $O$, et al Atrial natriuretic peptide (ANP) in rat gastrointestinal tract. FEBS Lett 1988 ; 233: 79-82.

22 Petterson A, Jönsson CO. Effects of atrial natriuretic peptide (ANP) on jejunal net fluid absorption in the rat. Acta Physiol Scand 1989; 136: 419-26.

23 Lübcke R, Brunner J, Hutcheson FAR, Barbezat GO. Only pharmacological doses of atrial natriuretic peptide (arANP) affect intestinal ion transport in non-volume-expanded rats. Gut (in press).

24 Humphreys MH, Laurence EE. The mechanism of decreased intestinal sodium and water absorption after acute volume expansion in the dog. $\mathcal{F}$ Clin Invest 1971; 50: 2355-67.

25 Waldman SA, Rapoport RM, Murad F. Atrial natriuretic factor selectively activates particulate guanylate cyclase and elevates cyclic GMP in rat tissues. $\mathcal{F}$ Biol Chem 1984; 259: 14332-4.

26 Gerzer R, Witzgall H, Tremblay J, Gutkowska J, Hamet P. Rapid increase in plasma and urinary cyclic GMP after bolus injection of atrial natriuretic factor in man. $\mathcal{F}$ Clin Endocrino Metab 1985; 61: 1217-9.

27 Gerzer R, Weil J, Strom T, Müller T. Mechanism of action of atrial natriuretic factor: clinical consequences. Klin Wochenschr 1986; 64 (Suppl VI): 21-6. 